\title{
Keragaman Genetik Gen Hormon Pertumbuhan (GH|MboII) pada Itik Sikumbang Janti Menggunakan Penciri PCR-RFLP
}

\section{Genetic Diversity of Growth Hormone Genes (GH|MboII) on Sikumbang Janti Ducks using PCR-RFLP Founder}

\section{T. D. Nova*, Yurnalis dan A. K. Sari}

Fakultas Peternakan Universitas Andalas, Padang, 25163

E-mail: tertiaunand@ymail.com

(Diterima: 30 November 2015; Disetujui: 18 Januari 2016)

\begin{abstract}
ABSTRAK
Penelitian ini bertujuan untuk mengetahui keragaman gen hormon pertumbuhan $(\mathrm{GH})$ dengan enzim MboII pada itik Sikumbang Janti dengan menggunakan penciri PCR-RFLP (polymerase chain reaction-restriction fragment length polymorphism). Penelitian ini menggunakan sebanyak 50 sampel darah itik Sikumbang Janti. Sampel darah itik Sikumbang Janti diambil melalui vena achilaris sebanyak $\pm 1 \mathrm{ml}$. DNA sampel darah diisolasi menggunakan protocol Genomik DNA Purification Kit (Promega). DNA total diamplifikasi menggunakan sepasang primer $\mathrm{F}$ : 5'-CTG GAG CAG GCA GGA AAA TT3' dan R: 5'-TCC AGG GAC AGT GAC TCA AC-3' yang menghasilkan fragmen exon 1 gen GH dengan panjang $801 \mathrm{bp}$. Produk amplifikasi direstriksi dengan menggunakan MboII yang mengenali

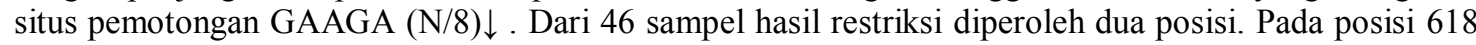
bp dengan genotip yaitu genotip heterozigot (+/-) yang terdiri dari 3 pita (266 bp, 535 bp dan 801 bp), genotip homozigot (+/+) yang terdiri dari 3 pita (109 bp, 266 bp, 426 bp) dan genotip homozigot (-/-) yang terdiri dari 1 pita ( 801) dan terdapat dua tipe alel, yaitu alel (+) dan all (-), all (+) sebesar 0,79 dan alel (-) sebesar 0,21 . Sedangkan pada posisi 727 bp memiliki genotip yaitu genotip heterozigot $(+/-)$ yang terdiri dari 3 pita (109 bp, $266 \mathrm{bp}, 426 \mathrm{bp}$ ), dan genotip homozigot (-/-) yang terdiri dari 3 pita dan terdapat dua tipe alel, yaitu frekuensi alel (+) sebesar 0,61 dan frekuensi alel (-) sebesar 0,39. Dari hasil penelitian ini dapat disimpulkan bahwa gen GH-MboII memiliki keragamanan yang tinggi serta menunjukkan adanya keseimbangan atau tidak menyimpang dari keseimbangan Hardy Weinberg pada posisi keragaman 618 bp dan pada posisi 727 dalam ketidakseimbangan Hardy Weinberg.
\end{abstract}

Kata kunci: Itik Sikumbang Janti, gen GH (hormon pertumbuhan), enzim MboII

\section{ABSTRACT}

This study aimed at determinating the gene diversity of growth hormone (GH) by the enzyme MboII identifier at ducks of Sikumbang Janti using PCR-RFLP (polymerase chain reaction-restriction fragment length polymorphism). This study used 50 blood samples of Sikumbang Janti ducks, taken through a vein achilaris as much as $\pm 1 \mathrm{ml}$. DNA blood samples were isolated using the protocol Genomic DNA Purification Kit (Promega). Total DNA was amplified using primer pair F: 5'-CTG CAG GCA GGA GAG AAA TT-3 'and R: 5'-TCC AGG TCA GAC GAC AGT AC-3' which resulted in exon 1 fragment $G H$ gene with a length of $801 \mathrm{bp}$. Amplification products were restricted by using MboII which

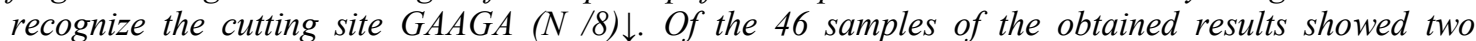
positions of restriction diversity. At position $618 \mathrm{bp}$ with a genotype that was heterozygous genotype (+/) consisting of 3 band (266 bp, $535 \mathrm{bp}$ and $801 \mathrm{bp}$ ), genotype homozygous (+/+), which consists of three band (109 bp, $266 \mathrm{bp}, 426 \mathrm{bp}$ ) and genotype homozygous (- /-), which consists of one band (801). There were two types of alleles, the GH-MboII (+) of 0.79 and (-) 0.21 . At the position 727 bp genotypes that genotype was heterozygous (+/+), consisting of three band (109 bp, $266 \mathrm{bp}, 426 \mathrm{bp}$ ), and genotype homozygous (-/-), which consists of three band (266 bp, $535 \mathrm{bp}$ and $801 \mathrm{bp})$. There were two types of alleles, the allele frequency (+) of 0.61 and allele frequency (-) 0.39. Therefore the GH gene-MboII have high diversity and show a balance or not deviate from Hardy-Weinberg equilibrium in diversity position 618 and at position 727 bp imbalance by Hardy-Weinberg.

Keywords: Sikumbang Janti Ducks, gene GH (growth hormone), enzyme MboII 


\section{PENDAHULUAN}

Beternak itik telah dilakukan sejak lama oleh masyarakat di Sumatera Barat. Itik merupakan sumber mata pencaharian keluarga. Biasanya, mereka memelihara itik dengan sistem gembala. Setiap pagi hingga sore peternak mengembalakan itik di sawahsawah untuk mendapatkan gabah- gabah yang tercecer sebagai sumber pakan. Sistem pemeliharaannya memang masih sangat sederhana. Namun, dari telur dan daging yang dihasilkan oleh itik peliharaannya, para peternak di pedesaan mampu memenuhi kebutuhan hidup keluargannya. Itik telah menjadi salah satu pilihan usaha penyedia telur dan daging sehingga dapat dijadikan ternak andalan.

Ternak itik merupakan salah satu jenis ternak unggas penghasil telur dan daging yang potensial. Populasi ternak itik tersebar diseluruh pelosok Nusantara mulai dari daerah perkotaan sampai pedesaan. Daging dan telur itik cukup digemari oleh masyarakat Indonesia. Menurut Bharoto (2001) jenis-jenis itik di Indonesia adalah itik Tegal, itik Mojosari, itik Alabio, itik Manila (entok), dan itik Bali. Penamaan dan pengelompokan jenis-jenis itik tersebut berdasarkan nama daerah tempat itik berkembang. Di Sumatera Barat itik lokal yang berkembang adalah itik Pitalah, itik Kamang, dan itik Bayang. Harahap, Arbi, Tami, Azhari dan Bandaro (1980) menyatakan bahwa dilihat dari fenotip itik yang dipelihara di Sumatera Barat seperti itik di pulau Jawa yang berdarah Indian Runner.

Menurut Dirtjen Peternakan (2013) populasi itik di Sumatera Barat terus meningkat dengan tingkat pertumbuhan itik $7 \%$, populasi sementara mencapai 1.201 .892 ekor pada tahun 2012. Sumbangan produksi daging itik pada tahun tersebut mencapai 703 ton pertahun atau 3\% dari produksi daging unggas nasional. Kelebihan ternak itik dibandingkan unggas lainnya adalah harga produknya lebih mahal, lebih stabil dan lebih tahan terhadap penyakit sehingga resiko pemeliharaannya tidak banyak.
Itik merupakan sumber daya genetik yang tinggi keanekaragamannya, baik dalam hal jenis maupun potensi produksinya. Ternak itik juga mempunyai potensi untuk dikembangkan karena memilki daya adaptasi yang cukup baik. Itik memiliki banyak kelebihan dibandingkan ternak unggas lainnya, diantaranya adalah ternak itik lebih tahan terhadap penyakit. Selain itu, itik memilki efisiensi dalam mengubah pakan menjadi daging yang baik (Akhdiarto, 2002). Salah satu itik lokal di Sumatera Barat adalah itik Sikumbang Janti yang merupakan itik petelur lokal dan itik ini berasal dari kota payakumbuh khususnya di Kenagarian Koto Baru Payobasuang.

Keragaman genetik sangat diperlukan dalam upaya pemuliaan ternak, karena dengan diketahuinya keragaman genetik ternak dimungkinkan untuk membentuk bangsa ternak baru melalui seleksi dan sistem perkawinan (Tixier-Boichard, 2009). Ismoyowanti dan Purwantini (2010) menyatakan bahwa identifikasi dan karakterisasi populasi itik lokal sangat penting dilakukan untuk identifikasi plasma nutfah dan pengembangan program pemuliaan.

Gen-gen yang diduga memiliki pengaruh pada pertumbuhan ternak diantaranya adalah Gen Growth Hormone (GH), GHR, GHRL, dan IGF1 telah digunakan sebagai gen kandidat dalam mencari keterkaitan antara genotipe dengan fenotipe pada ternak (Yon et al., 1990).

Berdasarkan pemaparan diatas, maka dilakukan penelitian ini mengenai "Keragaman Genetik Gen Hormon Pertumbuhan (GH|MboII) pada Itik Sikumbang Janti Menggunakan Penciri PCR-RFLP”.

\section{METODE}

\section{Metode Penelitian}

Penelitian ini dilakukan dengan metode eksperimen di Laboratorium Bioteknologi Ternak Fakultas Peternakan Unand. 
Sampel darah itik diambil $\pm 1 \mathrm{ml}$ melalui vena achilaris menggunakan jarum suntik (Disposible Syringe), dimasukkan dalam tabung vaccutainer EDTA dan disimpan pada suhu $-20^{\circ} \mathrm{C}$

\section{Isolasi DNA}

Isolasi DNA dilakukan dari sampel darah menggunakan genomic DNA purification kit dari Promega dengan prosedur sebagai berikut (Yurnalis, 2014):

1. Disiapkan tabung microcentrifuge $2 \mathrm{ml}$ yang di isi dengan cell lysis sebanyak $300 \mu 1$.

2. Dikocok tabung sampel darah, kemudian diambil sebanyak $50 \mu 1$, dan dimasukkan ketabung yang telah berisi cell lysis, agar tercampur rata tabung dibolak-balik sebanyak 5-6 kali.

3. Kemudian diinkubasi selama 10 menit lalu dicampurkan sampel darah dan cell lysis pada temperature ruang, sambil dibolak balik sebanyak 3 kali kemudian disentrifuse pada kecepatan 14000 rpm selama 30 detik.

4. Setelah disentrifuse buang supernatant hati-hati endapan jangan sampai ikut terbuang.

5. Selanjutnya ditambahkan kembali cell lysis sebanyak $300 \mu 1$, lalu disentrifuse pada kecepatan $14000 \mathrm{rpm}$ selama 30 detik. Kemudian dibuang supernatant dan endapan yang tinggal di tabung selanjutnya divortex selama 10-15 detik sehingga endapan tercampur rata.

6. Setelah itu ditambahkan larutan nuclei lysis sebanyak $500 \mu \mathrm{l}$ pada tabung hasil cell lysis di lysis dengan menggunakan pipet larutan untuk memecah sel darah. Kemudian diinkubasi selama 1 jam dalam waterbath pada temperature $37^{\circ} \mathrm{C}$. Jika setelah diinkubasi masih terlihat gumpalan, tambahkan $100 \mu \mathrm{l}$ larutan nuclei lysis.

7. Setelah diinkubasi ditambahkan larutan protein preciptasi sebanyak $200 \mu \mathrm{l}$ lalu divortex selama 20 detik, kemudian disentrifuse pada kecepatan 14000 rpm selama 3 menit. Selanjutnya pindahkan supernatant kedalam tabung eppendorf baru yang berisi $300 \mu 1$ Isopropanol.
8. Dicampur ratakan larutan isopropanol dengan membolak-balik secara perlahan tabung sampai terlihat benang-benang DNA, kemudian disentrifuse pada kecepatan 14000 rpm selama 1 menit. Kemudian tabung larutan yang berisi DNA akanterlihat sebagai pellet putih. Buang cairan dan ditambahkan larutan ethanol $70 \%$ sebanyak $300 \mu \mathrm{l}$. Kemudian dibolak balik tabung secara perlahan untuk mencuci pellet, kemudian disentrifuse (14000 rpm) selama 1 menit.

9. Buang cairan ethanol, balikan tabung diatas kertas tissue steril, lalu didiamkan hingga kering selama \pm 20 menit.

10. Lalu ditambahkan larutan DNA rehydration sebanyak $100 \mu \mathrm{l}$ ke dalam tabungsambil tabung di typping sehingga pellet larut atau didiamkan pada suhu $4^{\circ} \mathrm{C}$ semalam dan kemudian di simpan dalam freezer pada temperatur $-20^{\circ} \mathrm{C}$.

11. Untuk melihat hasil, DNA yang telah di isolasi dilakukan elektroforesis (Thermo Scientific) pada gel agarose $1 \%$.

\section{Amplifikasi Gen GH}

DNA total hasil isolasi, selanjutnya diamplifikasi menggunakan sepasang primer F : 5',CTG GAG CAG GCA GGA AAA TT-3' dan R: 5'-TCC AGG GAC AGT GAC TCA AC-3' (Yurnalis, 2014).

Pereaksi amplifikasi PCR menggunakan Master Mix (Thermo Scientific) dengan komposisi sebagai berikut:

a. Sampel DNA sebanyak $2 \mu 1$.

b. Master mix sebanyak $15 \mu 1$.

c. Campuran primer $\mathrm{F}$ dan $\mathrm{R}$ sebanyak $3 \mu 1$.

d. Water nuclease-free sebanyak $10 \mu 1$.

Amplifikasi invitro dilakukan dengan menggunakan mesin PCR (Eppendorf Mastercycler gradient) dengan program pradenaturasi pada temperatur $95^{\circ} \mathrm{C}$ selama 45 detik, annealing pada temperatur $60^{\circ} \mathrm{C}$ selama 45 detik dan extensi $72^{\circ} \mathrm{C}$ selama 1 menit dan extensi akhir $72^{\circ} \mathrm{C}$ selama 5 menit dengan 35 siklus. 
Untuk melihat hasil amplifikasi gen $\mathrm{GH}$, dielektroforesis menggunakan agarose $1,5 \%$ yang diwarnai dengan pewarnaan ethidium bromide dan hasilnya di amati dengan menggunakan UV transiluminator. Amplifikasi gen GH dikatakan berhasil jika pada gel agarose terlihat pita-pita pada posisi/ukuran pada sumur yang berisi sampel DNA produk PCR sesuai dengan target sepanjang $801 \mathrm{bp}$ yang dapat di tentukan dengan membandingkan posisi pita yang terbentuk dengan posisi pita DNA ladder. Kemudian hasil elektroforesis didokumentasikan dengan kamera.

\section{Restriksi Enzim MboII}

Setelah selesai proses PCR dilakukan restriksi enzim dengan menggunakan enzim MboII. Penentuan genotipe menggunakan pendekatan RFLP dengan menggunakan produk PCR $15 \mu \mathrm{l}$ lalu dimasukkan enzim MboII $15 \mu$ l, kemudian diinkubasi pada suhu $37^{\circ} \mathrm{C}$ selama 4 jam. Produk pemotongan DNA tersebut divisualisasikan pada gel agarose $2 \%$ dengan buffer $0,5 \times$ TBE (Tris Borat EDTA) yang diwarnai dengan ethidium bromide, dan dijalankan menggunakan power supply electrophoresis pada tegangan 100 Volt. Hasil elektroforesis diamati dengan bantuan sinar UV transiluminator. Pita-pita DNA yang muncul dibandingkan dengan marker untuk diketahui panjang fragmennya dan jumlah pita DNA dari setiap sampel dibandingkan untuk menentukan genotipe pita DNA. Penentuan alel GH|MboII (+) dan $\mathrm{GH} \mid \mathrm{MboII}$ (-) ditunjukan dengan jumlah dan ukuran besarnya fragmen yang terpotong.

\section{Analisis Data}

Analisis diskripsi untuk melihat keragaman sekuen GH dilakukan menurut prosedur SNP stat (Sole et al., 2006) sebagai berikut :

a) Frekuensi genotip dihitung berdasarkan jumlah alel suatu genotif di bagi dengan jumlah sampel:

$$
f_{1}=\frac{\sum x}{N}: X_{1}=\text { genotip yang diamati }
$$

b) Frekuensi alel dihitung dengan menjumlah semua alel dibagi dengan $2 \mathrm{~N}$

$$
f_{2}=\frac{\sum x_{1}}{2 N}: x_{1}=\text { alel yang diamati }
$$

c) Keseimbangan Hardy-weinberg diuji dengan chi-square $\left(\chi^{2}\right)$ (Hartl, 1988).

Pengujian keseimbangan Hukum Hardy-Weinberg pada populasi itik dilakukan dengan menggunakan uji chisquare untuk mengetahui apakah data pengamatan diperoleh menyimpang atau tidak menyimpang dari yang diharapkan.

Keterangan :

$$
X_{h}{ }^{2}=\sum \frac{(0-E)^{2}}{E}
$$

$X_{h}{ }^{2}=$ chi-square

$O=$ jumlah pengamatan genotipe ke-i

$E=$ jumlah harapan genotip ke-i

\section{HASIL DAN PEMBAHASAN}

\section{Isolasi DNA Total}

Isolasi DNA Genomik dari darah itik dilakukan menggunakan protocol Genomik DNA Purification Kit dari Promega yang telah dimodifikasi. Sampel darah yang sudah di isolasi untuk mengetahui keberhasilan dari isolasi DNA tersebut maka dilakukan elektroforesis seperti pada Gambar 1 dibawah ini. Dari hasil elektroforesis menunjukkan bahwa pita DNA yang diperoleh dari isolasi darah menghasilkan pita DNA yang jelas dan bersih hal ini menunjukan kualitas DNA yang dihasilkan baik. Langkah awal yang sangat menentukan dalam keberhasilan penelitian molekuler yang berbasis pada DNA adalah kualitas DNA yang diperoleh dari tahapan isolasi. Kemurnian dan kualitas DNA yang diperoleh dari tahap ini akan sangat menentukan dalam penelitianpenelitian biologi molekuler.

Tiga langkah utama dalam isolasi DNA adalah perusakan dinding sel atau lisis, pemisahan DNA dari bahan padat seperti selulosa dan protein, serta pemurnian DNA (Surzycki, 2000). DNA yang diperoleh dari hasil isolasi darah ada yang terlihat smear, hal ini menunjukkan bahwa metabolit metabolit yang terkandung di dalam darah tidak dapat dibersihkan secara sempurna pada proses isolasi, sehingga tidak diperoleh 


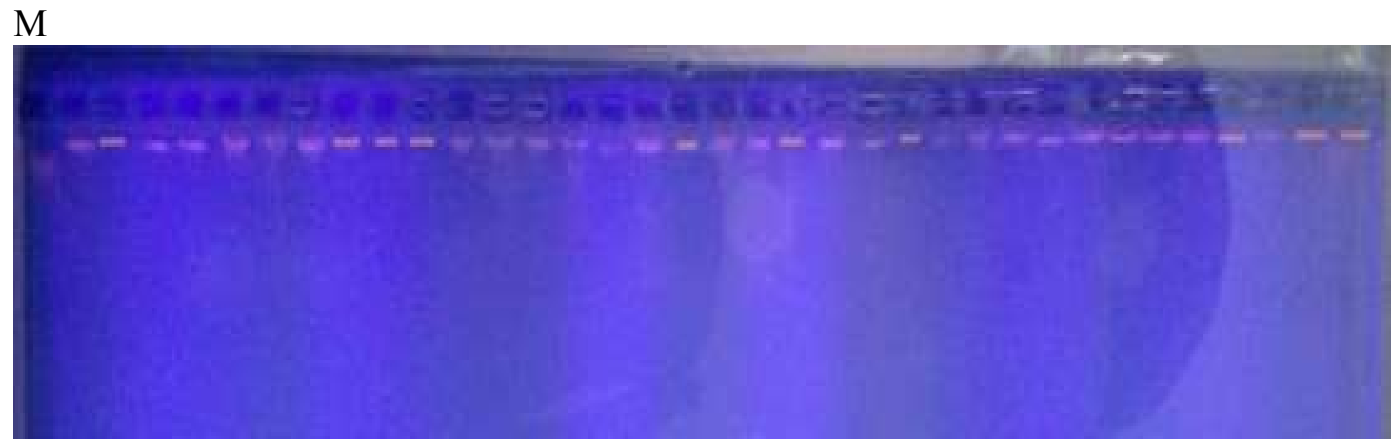

Gambar 1. Hasil elektroforesis isolasi DNA nomor sampel 1-35 Keterangan : $\mathrm{M}=$ marker

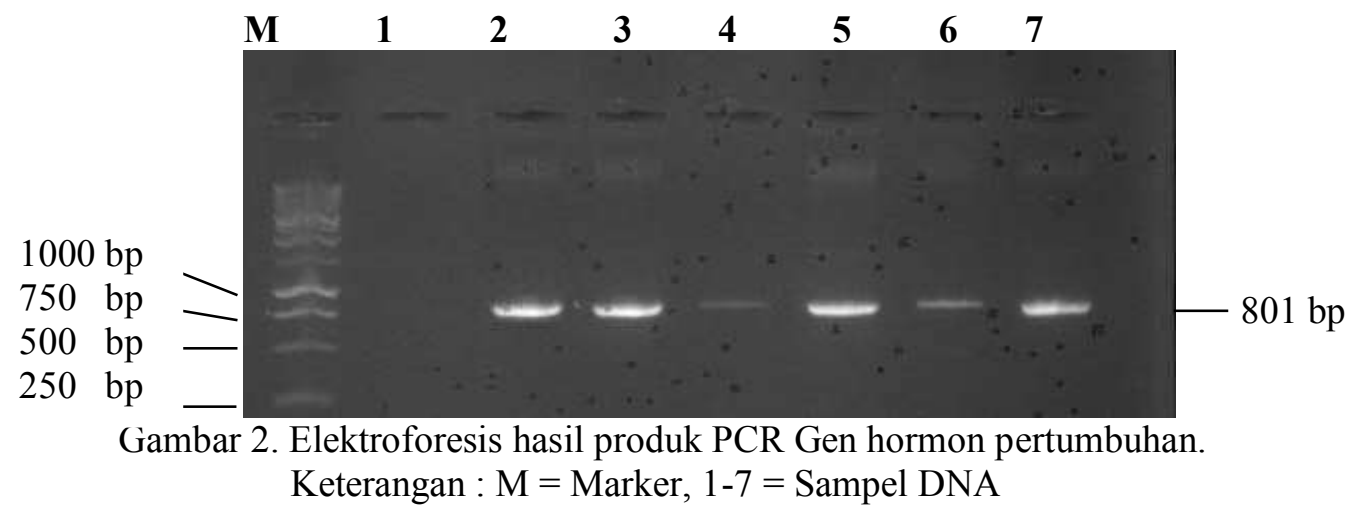

DNA yang murni. Sedangkan pada hasil isolasi darah yang terlihat jelas proses pemurnian DNA dapat terjadi lebih sempurna sehingga dapat diperoleh DNA yang murni. Hal ini ditandai dengan pita DNA yang jelas dan bersih. Menurut Peccia dan Hernandez (2006) bahwa pada dasarnya prinsip dari isolasi DNA terdiri dari melisiskan sel dan memurnikan asam nukleat (DNA). Pemurniaan DNA merupakan proses untuk memisahkan DNA dari lisat sel (protein, karbihidrat, lipid) dan kontaminan lain. Pada hasil elektroforesis ini terdapat sumur (slot) yang kosong atau tidak terdapat pita. Hal ini disebabkan karena diduga pada waktu menginjeksi sampel keluar dari slot, adanya kontaminasi sehingga DNA yang harus diambil supernatan ikut terbuang dengan hasil sentrifugasi yang dibuang serta kesalahan dalam memasukan bahan dan komposisinya. Hasil elektoforesis tersebut dilihat dengan transilluminator UV dan dipotret pada Gambar 1

\section{Amplifikasi Gen Hormon Pertumbuhan}

Amplifikasi gen hormon pertumbuhan dari DNA total itik Sikumbang Janti, menggunakan metode PCR dengan suhu annealing $60^{\circ} \mathrm{C}$ selama 3 jam menggunakan pasangan primer $\mathrm{F}: 5^{\prime}-\mathrm{CTG} \mathrm{GAG} \mathrm{CAG}$ GCA GGA AAA TT-3' dan R: 5'-TCC AGG GAC AGT GAC TCA AC-3' (Yurnalis, 2014). Pada elektroforesis hasil amplifikasi yang dilakukan, dengan menggunakan gel agarose $1,5 \%$, dari 50 sampel DNA gen GH itik Sikumbang Janti diperoleh hasil produk PCR sebanyak 46 slot blok gel (sumur). Sampel DNA yang tidak teramplifikasi diduga karena terjadi mutasi dititik pemotongan basa DNA gen $\mathrm{GH}$ yang menyebabkan perubahan dari basa DNA gen $\mathrm{GH}$, sehingga pasangan primer yang digunakan tidak dapat mengamplifikasi fragmen yang dikenali, tidak menempelnya primer pada DNA target selama proses annealing. Ketidakberhasilan amplifikasi DNA ditandai dengan tidak terlihat pita DNA pada saat dilakukan 


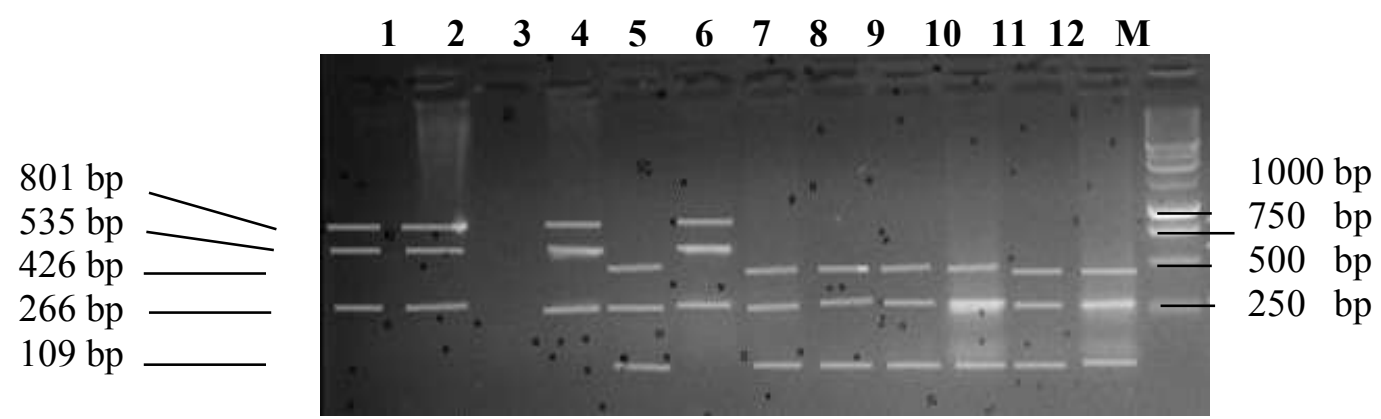

Gambar 3. Hasil restriksi fragmen Gen GH menggunakan enzim MboII.

Posisi pemotongan enzim dapat dilihat pada gambar berikut ini :

301 aggtgtcccagtctggcttgtcagccctgttaactgtgggccagaccctgcctggagcag

361 gcaggaaattaggagcactttctatctatgcggggaaattccaccatgtaaaagcactg

421 atctgatttggggtggctcttccatgatgataaaaccgttatttgcaataaacagcagaa

481 tatggagaaatcattcagtgctaatttcatccctaggcaaacatcctccccaacctttcc

541 atctatgtataaatgactacaattaggtagcaccattgcgaacacgtgtgcatttatgca

601 tggagaagatatagagaggttgttgtgatcatgaacacatatatacattttaaacagacc

661 ccctactatataaggggtgtctcaacagttgccattaccagcctagatgaaaggaagaaa

721 cattcactttcaagcaacatctgagcaactctccaggcagaatggctccaggtactctt

781 ctttatttcagtttacgaggattgccaatgcggctacaggcagcattgtgtccaaagaag

841 ggcaataaagctggtgaagggtctagagaacaagtcttattaggagcagccgtgggcact

901 ggggttgtttagcttggagaaaggtggctcaggagagaccttaccacaccctacaatta

961 ccttaaaggaggctgtagcaaggtggggatcaggctcttctcccaggtactaagtggtaa

1021 gatgaggggaaatggcctcaagttgtgccaggggaggtttaggttggatattagaagaag

1081 tttcttactgaaagggttgtgtggcactggaataggctgcccagggaagtggttgagtc

1141 actgtccctggaggtcatcatgaaacatgtagatgtagaagttagtagtatgttttcatg

Gambar 4. Posisi pemotongan gen GH|MboII menghasilkan fragmen 109 bp, 266 bp, 426 bp dan 535 bp.

elektroforesis menggunakan gel agarose $1,5 \%$. Hasil elektoforesis dapat dilihat pada Gambar 2.

Proses amplifikasi dinyatakan berhasil apabila dalam satu slot blok gel (sumur) terlihat satu pita DNA atau satu fragmen yang berukuran sesuai dengan yang diharapkan. Hal ini sesuai dengan pendapat Rojas et al. (1993), bahwa fragmen DNA dengan ukuran tersebut sesuai dengan ukuran yang diharapkan dengan primer. Suatu primer dikatakan tidak spesifik, apabila dalam satu sumur tersebut menghasilkan produk amplikasi lebih dari satu fragmen, atau panjang pita DNA yang dihasilkan tidak sesuai dengan prediksi primer yang digunakan. Dari gambar di atas bahwa hasil amplikasi gen GH dengan primer tersebut dapat dinyatakan teramplikasi secara spesifik karena hanya terdapat satu pita DNA di setiap sumur pada saat di lakukan elektroforesis. Keberhasilan amplifikasi gen GH sangat ditentukan oleh kondisi penempelan primer pada DNA genom (gen target). Berdasarkan pasangan primer yang digunakan sesuai dengan rancangan Yurnalis, (2014) menunjukan hasil bahwa panjang produk PCR hasil amplikasi gen GH adalah 801 bp yang terletak pada daerah exon 1 .

\section{Keragaman Gen GH|MboII}

Keragaman gen hormon pertumbuhan diketahui dengan menentukan alel dan genotip pada setiap individu melalui pendekatan PCR-RFLP menggunakan enzim restriksi MboII. Nei dan Kumar (2000) menyatakan bahwa gen dikatakan polimorfik apabila salah satu alelnya kurang dari $99 \%$. Bagian pada DNA yang dikenai aksi 
pemotongan oleh enzim restriksi ini dinamakan sekuen pengenal. Enzim ini hanya mengenali situs pemotongan GAAGA (N/8). Dari hasil amplifikasi produk PCR fragmen gen $\mathrm{GH} \mid \mathrm{M} b o I I$ yang dielektroforesis pada gel agarose $2 \%$ diperoleh tiga macam fragmen, yaitu fragmen yang dapat dipotong dengan satu pemotongan dikenal dengan $(+/+)$, fragmen gabungan dengan dua pemotongan dikenal dengan (+/-) dan tidak terpotong (-/-) dan 2 alel + dan -. Untuk menentukan alel $\mathrm{GH} \mid \mathrm{MboII}(+)$ dan $\mathrm{GH} \mid \mathrm{MboII}(-)$ ditunjukkan dengan jumlah dan ukuran besarnya fragmen yang terpotong lalu dicocokan dengan marker yang digunakan. Hasil penelitian ini dapat disimpulkan bahwa terjadi keragaman pada gen hormon pertumbuhan dengan enzim MboII karena terdapat perbedaan situs pemotong dari hasil elektroforesis pada gel agarose 2\% yang dapat dilihat pada Gambar 3 .

Pada Itik Sikumbang Janti dengan menggunakan enzim MboII terdapat 2 titik pemotongan pita DNA, pemotongan pertama dengan posisi $266 \mathrm{bp}, 535 \mathrm{bp}$ dan $801 \mathrm{bp}$ keragaman gen hormon pertumbuhan terjadi pada posisi 618 bp kemudian pada pemotongan kedua dengan jumlah basa 109 bp, 266 bp dan 426 bp keragaman gen hormon pertumbuhan terjadi pada posisi 727 bp. Pada posisi 618 bp mempunyai genotip +/- , +/+ dan -/- dan posisi 727 bp mempunyai genotip -/- dan +/+ yang dapat dilihat pada Gambar 3.

\section{Frekuensi Genotip dan Frekuensi Alel}

Frekuensi alel yaitu frekuensi relatif dari suatu alel dalam populasi atau jumlah suatu alel terhadap jumlah total alel dalam suatu populasi (Nei dan Kumar, 2000). Pemotongan produk PCR menggunakan enzim MboII menghasilkan fragmen dengan pola potongan yang beragam (polimorfik). Frekuensi genotip dan frekuensi alel gen GH|MboII pada Itik Sikumbang Janti dilihat dan dihitung berdasarkan situs pemotongan enzim MboII yang divisualisasikan dari hasil elektroforesis pada gel agarose $2 \%$. Polimorfisme atau keragaman dapat ditunjukkan dengan adanya dua alel atau lebih dalam satu populasi. Hasil frekuensi alel dan genotip pada Itik Sikumbang Janti dapat dilihat pada Tabel 1.

$$
\text { Keragaman pada posisi } 618
$$

mempunyai genotip GH|MboII $(+/+)$ dengan nilai frekuensi genotip sebesar 0,61, serta genotip GH|MboII (+/-) dengan nilai frekuensi genotip sebesar 0,37 dan $\mathrm{GH} \mid \mathrm{MboII}$ (-/-) dengan nilai frekuensi genotip sebesar 0,02 . Demikian pula yang didapat pada frekuensi alel $\mathrm{GH} \mid$ MboII $(+)$ lebih tinggi dengan frekuensi 0,79 dibandingkan dengan frekuensi alel gen GH $\mid$ MboII (-) sebesar 0,21. Sedangkan keragaman untuk posisi pemotongan 727 bp memiliki genotip $\mathrm{GH} \mid \mathrm{MboII}(+/+)$ dengan nilai frekuensi genotip sebesar 0,61, dan genotip GH|MboII (-/-) dengan nilai frekuensi genotip sebesar 0,39. Dengan frekuensi alel $\mathrm{GH} \mid \mathrm{MboII}(+)$ lebih tinggi dengan frekuensi 0,61 dibanding dengan frekuensi alel gen GH|MboII (-) sebesar 0,39 . Dari hasil analisa frekuensi alel dinyatakan bahwa terdapat keragaman yang tinggi pada gen hormon pertumbuhan pada itik Sikumbang Janti yang direstriksi dengan enzim MboII karena terdapat perbedaan panjang fragmen DNA. Sesuai dengan pendapat Nei dan Kumar (2000) bahwa gen dikatakan polimorfik apabila salah satu alelnya kurang dari $99 \%$.

Tabel 1. Hasil frekuensi alel dan genotip pada Itik Sikumbang Janti

\begin{tabular}{|c|c|c|c|c|c|c|}
\hline \multirow{2}{*}{$\begin{array}{l}\text { Keragaman Posisi Gen } \\
\text { Pemotongan (bp) }\end{array}$} & \multicolumn{3}{|c|}{ Frekuesi Genotip } & \multicolumn{2}{|c|}{ Frekuensi Alel } & \multirow{2}{*}{$X_{h}{ }^{2}$} \\
\hline & $+/+$ & $+/-$ & $-/-$ & + & - & \\
\hline 618 & 0,61 & 0,37 & 0,02 & 0,79 & 0,21 & 0,728 \\
\hline
\end{tabular}




\section{Keseimbangan Hardy-Weinberg}

Suatu populasi dinyatakan dalam keseimbangan Hardy-Weinberg, jika frekuensi genotip $\left(p^{2}, 2 p q\right.$ dan $\left.q^{2}\right)$ dan acak. Hasil Pengujian keseimbangan Hukum Hardy-Weinberg pada populasi Itik Sikumbang Janti GH|MboII dilakukan dengan menggunakan uji chi-square untuk mengetahui apakah data pengamatan diperoleh menyimpang atau tidak menyimpang dari yang diharapkan. Berdasarkan hasil penelitian menunjukkan bahwa adanya keseimbangan Hukum Hardy Weinberg dimana $X_{h}{ }^{2}(0,728) \leq X_{h}{ }^{2}(0,05)$ untuk posisi pemotongan pada 618 bp dan $X_{h}{ }^{2}(39,249) \geq X_{h}{ }^{2}(0,01)$ untuk posisi pemotongan pada 727 bp menunjukkan adanya penyimpangan atau dalam ketidakseimbangan Hardy Wienberg, dapat dilihat pada Tabel 1. Pada posisi pemotongan $727 \mathrm{bp}$ data diperoleh tidak seimbang diduga karena sudah ada kegiatan seleksi yang dilakukan, tidak adanya perkawinan secara acak, tidak terkontrolnya sistem perkawinan sehingga ada peluang terjadinya seleksi,terjadi penyempitan pada populasi (bottleneck effect) dan sudah terjadi migrasi.

\section{KESIMPULAN}

Dari hasil penelitian ini dapat disimpulkan bahwa:

1. Terdapat keragaman gen $\mathrm{GH} \mid \mathrm{M} b o I I$ pada itik Sikumbang Janti dengan pemotongan

2. Pada posisi pemotongan $618 \mathrm{bp}$, frekuensi alel dan frekuensi genotip yaitu; frekuensi alel $(+)$ sebesar 0,79, frekuensi alel (-) sebesar 0,21 dan genotip $\mathrm{GH} \mid \mathrm{M} b o I I(+/+)$ dengan nilai frekuensi genotip sebesar 0,61 , serta genotip GH|MboII (+/-) dengan nilai frekuensi genotip sebesar 0,37 dan $\mathrm{GH} \mid \mathrm{MboII}$ (-/-) dengan nilai frekuensi genotip sebesar 0,02 .

3. Pada posisi pemotongan $727 \mathrm{bp}$, frekuensi alel dan frekuensi genotip frekuensi alel ( $p$ dan $q$ ) konstan dari generasi ke generasi, karena akibat penggabungan gamet yang terjadi secara

yaitu; frekuensi alel $(+)$ sebesar 0,61 , frekuensi alel (-) sebesar 0,39 dan genotip $\mathrm{GH} \mid \mathrm{MboII}(+/+)$ dengan nilai frekuensi genotip sebesar 0,61, dan genotip GH|MboII (-/-) dengan nilai frekuensi genotip sebesar 0,39.

4. Pada posisi pemotongan 618 bp menunjukkan adanya keseimbangan atau tidak menyimpang dari keseimbangan Hardy Weinberg dan pada posisi pemotongan $727 \mathrm{bp}$ menunjukan dalam ketidakseimbangan Hardy - Weinberg.

\section{DAFTAR PUSTAKA}

Akhadiarto, S. 2002. Kualitas Fisik Daging Itik pada Berbagai Umur Pemotongan Pusat Pengkajiaan dan Penerapan Teknologi Budidaya Pertanian. BPPT.

Bharoto, K.D. 2001. Cara Berternak Itik. Aneka Ilmu, Semarang.

Direktorat Jenderal Peternakan dan Kesehatan Hewan. 2013. Daftar Populasi, Konsumsi, dan Produksi Ternak, Jakarta.

Harahap., D. A. Arbi, D. Tami, W. Azhari dan Dj. Dt. T. Bandaro. 1980. Pengaruh manajemen terhadap produksi telur itik di Sumatra Barat. P3T Universitas Andalas, Padang.

Ismoyowati and D. Purwantini. 2011. Genetic variability of Bali and Alabio duck on the basis of phenotypic and microsatellite. Asian J Poult Sci. 5 (3): 107-115

Peccia, J. and M. Hernadez. 2006. Incorporating polymerase chain reaction-based identification population characterization, and quantification of microorganisms into aerosol: A Review. Atmospheric Environment. 40: 3941-3961.

Rojas, M. R., R. L. Gilbertson, D. R. Russel, and D. P. Maxwel.1993. Use of degenerate primers in the polymerase 
Vol. 18 (1): 44-52

chain reactin to detect whitefly transmitted geminiviruses. Plant Disease. 71:340-347.

Sole, X., E. Guino, J. Valls, R Iniesta and V. Morena. 2006. SNPtats : a web tool for the analysis of association studies bioinformatic 22:1928-1929

Surzycki, S. 2000. Basic Techniques in Molecular Biology. Spinger-Verlag. Berlin. Heidelberg, New York.
Tixier-Boichard, M, A. Bordas and X. Rognon.2009. Characterisation and monitoring of poultry genetic resources. World's Poult Sci. 65: 272285.

Yoon, J. B., S. A. Berry., S. Seelig., and H. C. Towle. 1990. An indocible nuclear factor binds to a growth hormone regulated gene. Journal of biological chemistry 265 : 19947 - 19954. 